\title{
ETHNOPHARMACOLOGICAL THERAPIES IN THE TREATMENT OF DIABETES IN SERBIA
}

\author{
Višnja Madić ${ }^{1}$, Andrea Žabar Popović ${ }^{1}$, Marija Vukelić-Nikolić ${ }^{2}$, \\ Ljubiša Đorđević ${ }^{1}$, Perica Vasiljević ${ }^{1}$ \\ ${ }^{1}$ University of Niš, Faculty of Science and Mathematics, Department of Biology and Ecology, Niš, \\ Serbia \\ ${ }^{2}$ University of Niš, Faculty of Medicine, Institute of Biology and Human Genetics, Niš, Serbia
}

Summary. The use of ethnopharmacological therapies is a part of human tradition. For centuries, they have been used in the treatment of diabetes, as well as other illnesses. The aim of this study was to examine the frequency of traditional medicine use in Serbia. The study was conducted as an online survey in February 2018. 130 people were surveyed, 55.38 $\%$ of which were people diagnosed with diabetes. The most commonly used herbal substituents were $M$. piperita $\mathrm{L}$. $(21 \%)$, traditional herbal mixtures designed to regulate the primary and secondary diabetes complications (15\%), M. chamomilla L. $(13 \%)$ and pharmaceutical supplements based on traditional recipes (10\%). $100 \%$ of people with diabetes adhere to contemporary pharmacotherapy, while $25.86 \%$ of people without diabetes do not use pharmacotherapy, but exclusively traditional medicine. There is no significant difference between the diabetic population that uses traditional medicine $(51.34 \%)$ and the one who does not $(48.61 \%)$, whereas in non-diabetic population the difference is significant $(p<0.05)$ so that $87.93 \%$ of them regularly use medicinal herbs. More women than men use ethnopharmacological treatments $(p<0.05)$. The age of the respondents and their education also have an impact on the choice of therapy, so ethnopharmacological approaches are the most often used by faculty educated people aged 30 to 50 years. Moreover, people pay attention to the quality of supplements they use, i.e. $57.96 \%$ of people buy them in pharmacies, $29.55 \%$ with certified sellers, and only $12.49 \%$ at the local market.

Key words: diabetes, ethnopharmacology, pharmacotherapy.

\section{Introduction}

The use of ethnopharmacological therapies is a part of human tradition. For centuries, traditional medicine has been used in the treatment of diabetes, as well as other illnesses. It is a branch of complementary and alternative medicine (CAM) which is a set of medicinal systems, health care, actions, and products that at the moment are considered as a part of common medicine. (Snyder et al, 2009).

In the Balkans, traditional medicine is largely based on the use of medicinal plants, and it has been used either to prevent acute and chronic diseases or after the disease is diagnosed. Traditional medicine is used as the treatment for a variety of diseases, including Diabetes Mellitus. Diabetes is a chronic disease characterized by an absolute or relative lack of insulin, hyperglycemia, dyslipidemia, and neurovascular damage that can affect all systems of the patient's organism (Jenkins, 2016). It is a pandemic disease of the 21 st century. In 2015, there were 415 million adults and half a million children with diabetes glob-

Autor za korespondenciju: Višnja Madić, e-mail: visnja.madic@gmail.com

University of Niš, Faculty of Science and Mathematics, Department of Biology and Ecology, Višegradska 33, Niš, Serbia

Primljeno u redakciju 28. 6. 2018, rad prihvaćen za publikovanje 15. 9. 2018. 
ally, predicted to rise to over 642 million in the next 23 years. Every 6 seconds a person dies of diabetes (International Diabetes Federation (IDF), 2015). The situation in Serbia is also alarming, where 710000 people are diagnosed with diabetes and it is the fifth cause of death in the country. It is interesting that type 2 diabetes, which was until recently reserved mainly for the older population, is increasingly diagnosed in children and adolescents as well. (Institute of Public Health "Dr. Milan Jovanovic Batut", 2017).

In recent decades, the use of traditional medicine has become more and more popular, and complementary and alternative medicine market is worth more and more every year. It is estimated that it will generate a revenue of 196.87 billion US dollars by 2025. (Grand View Research, Inc, 2017) Annually, US citizens spend 30.2 billion US dollars out of pocket on CAM remedies (NCCIH, 2016). Traditional Chinese Medicine global market in medicinal plants is worth about 48 billion US dollars annually (WHO, 2012).

According to the World Health Organization, $80 \%$ of the human population relies on traditional medicine. (Farnsworth et al, 1985). Also, traditional medicine use has increased in European countries in the past decade, and more than $98 \%$ of European citizens rely on CAM. (Snyder et al, 2009).

There are many different reasons for this increase in the prevalence of traditional medicine use, but in general, they can be classified into three broad categories: inaccessibility of modern health care, fear of pharmacotherapy and cultural reasons.

Modern health care may be inaccessible for a variety of reasons, such as territorial inaccessibility, high costs of health care or poor organization of a certain health system.

Fear of pharmacotherapy can be justified (possible side effects caused by modern drugs) or unjustified (caused by personal beliefs). For example, the primary treatment for type 2 diabetes is going on a diet, doing exercises, and taking oral medications such as hypoglycemic drugs and/or insulin injection. Although modern treatments have achieved much progress in blood sugar control during recent decades, pharmacotherapy is still followed by side effects. Treatment with metformin is followed by many digestive - intestinal complications (Adusumilli, 2004), and weight gain is a common side effect for people who take insulin. This is one of the reasons why people often combine pharmacotherapy and phytotherapy.

Cultural heritage has a major impact on the prevalence of traditional medicine use, which is the most noticeable in multicultural countries such as USA and Australia. For example, in the USA, the prevalence of CAM use varies across the three groups, with $57 \%$ Vietnamese Americans, $53 \%$ Mexican Americans, and $29 \%$ non-Hispanic Whites. (Nguyen et al, 2014). The situation in Australia is similar, where most CAM users are overseas born individuals (63\%), and only $38 \%$ are Australian born CAM users. (Manya, 2012)

These three broad categories which cause such a high popularity of traditional medicine globally are overlapping, and the level of an overlap leads to the different prevalence of traditional medicine use in different countries, both in the population of people with diagnosed diabetes and in non - diabetic population. According to different researches, $14 \%$ of the Russian population regularly uses medicinal plants, and $44 \%$ of them occasionally (Shikov et al, 2014), while only $20 \%$ of the Dutch are relying on traditional medicine (Fisher, 1994). There is a somewhat higher prevalence of medicinal herb use in China (40\%) (Esmonde et al, 2008), Australia (46 \%) (Manya, 2012), UK (46 \%) (AlQathama, 2016), France (49 \%) (Fisher, 1994), Japan (50 \%) (Hori, 2008), Canada (50 \%) (Bradshaw, 2016; Jatau et al, 2016), Taiwan (61 \%) (Chang et al, 2011), Mexico (62 \%) (Argaex-Lopez, 2003), Germany (62\%) (Hartel et al, 2004), India (68 \%) (Kumar et al, 2006), USA (73\%) (Bell et al, 2006), Africa (80\%) (Esmonde et al, 2008) and Iran (88.4\%) (Sheikhrabori, 2017). 
Depending on the sample of the population surveyed, the number of respondents using traditional medicine varies. According to one study, $100 \%$ of the rural population of Serbia benefited from traditional methods of treatment (Pieroni et al, 2011), while another study shows that $94.57 \%$ of women and $82.3 \%$ of men on the territory of Niš, along with the standard therapy for type 2 diabetes, also use phytopharmacology. (Damjanovic et al, 2015)

The aim of this research was to determine the prevalence of the use of ethnopharmacological therapies in Serbia in two populations - people with diagnosed diabetes and people without diagnosed diabetes.

\section{Material and methods}

This was a cross-sectional survey conducted online with the help of Diabetes Association of Serbia, Diabetes Association of Belgrade, Serbia, and Diabetes Association of Niš, Serbia, during February 2018. The research was performed by surveying a total of 130 respondents.

The questionnaire comprised 11 questions using a combination of open and closed question response formats. Questions were divided into four domains related to demographic data (such as gender, age group, and educational status), health condition (diagnosed or undiagnosed diabetes), CAM usage (a type of phytotherapy remedies and place of purchasing), pharmacotherapy usage and the influence of health care professionals' advice. The research was performed by surveying a total of 130 respondents.

The data were statistically analyzed and processed using chi-square test of independence, in Microsoft Excel 2010. Statistical significance was accepted at $\mathrm{p}<0.05$.

\section{Results}

The sample comprised 130 people, $55.38 \%$ of which were people with diabetes, and $44.62 \%$ were non - diabetic. The mean age of the participants was $34.83 \pm 12.76$ years. $77.69 \%$ of participants were women. In total, $67.7 \%$ of the participants use traditional medicine. In both diabetic and non - diabetic population, there was a statistically significant difference $(\mathrm{p}<0.05)$ in the use of traditional medicine between genders $-19.23 \%$ female vs $9.23 \%$ male with diabetes; $28.46 \%$ female vs $10.76 \%$ male without diabetes who regularly use traditional medicine (Graph 1).

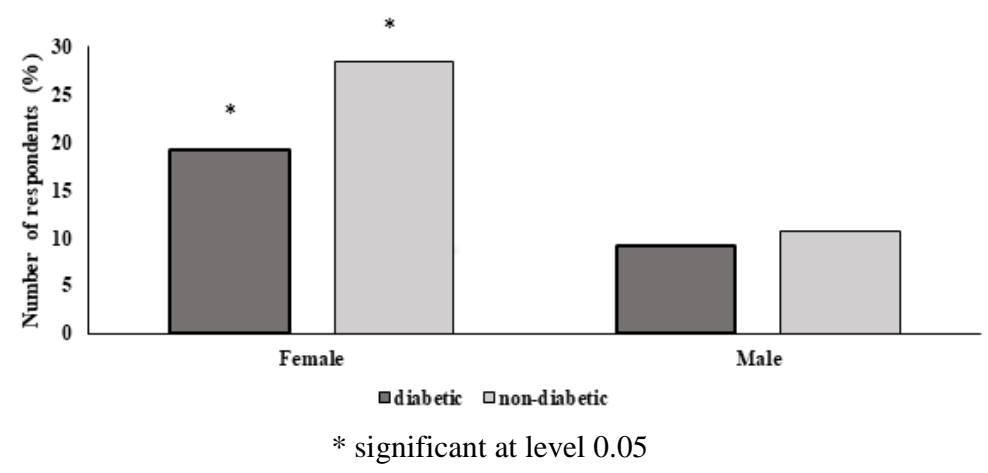

Graph 1. The frequency of the traditional medicine use in relation to gender differences in diabetic and non-diabetic population

Grafik 1. Frekventnost korišćenja tradicionalne medicine u zavisnosti od pola u dijabetičnoj i ne-dijabetičnoj populaciji 
There is no significant difference in the number of people with diabetes who use $(51.34 \%)$ and do not use traditional medicine $(48.61 \%)$, while the difference among respondents who have not been diagnosed with diabetes is significant. Thus, as many as $87.93 \%$ of these subjects regularly consume medicinal plants and/or substituents.

All subjects with diabetes use modern pharmacotherapy and adhere to the advice of doctors and/or pharmacists, while more than a quarter of subjects without diabetes $(26 \%)$ relies exclusively on traditional medicine.

The age of the respondents and their education also have an impact on the choice of therapy, so ethnopharmacological approaches are the most often used by faculty educated people (Graph 2) aged 30 to 50 years (Graph 3).

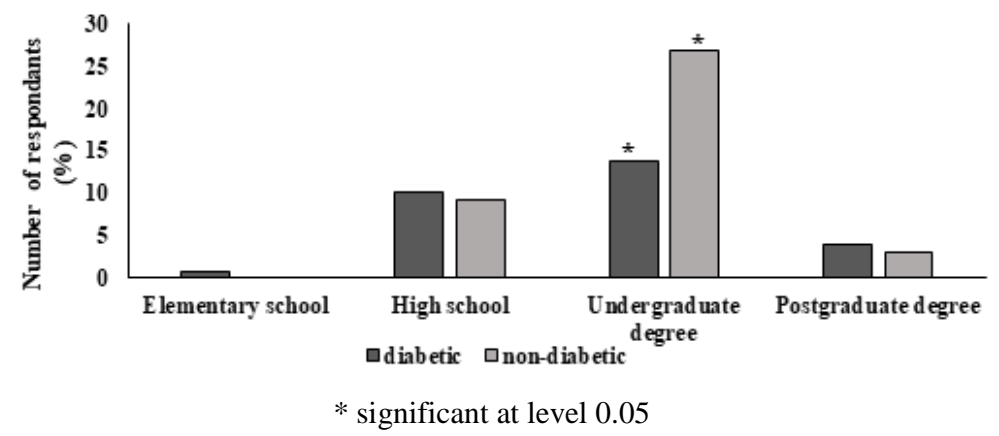

Graph 2. The frequency of traditional medicine use according to the education of respondents. Grafik 2. Frekventnost korišćenja tradicionalne medicine u odnosu na obrazovanje ispitanika

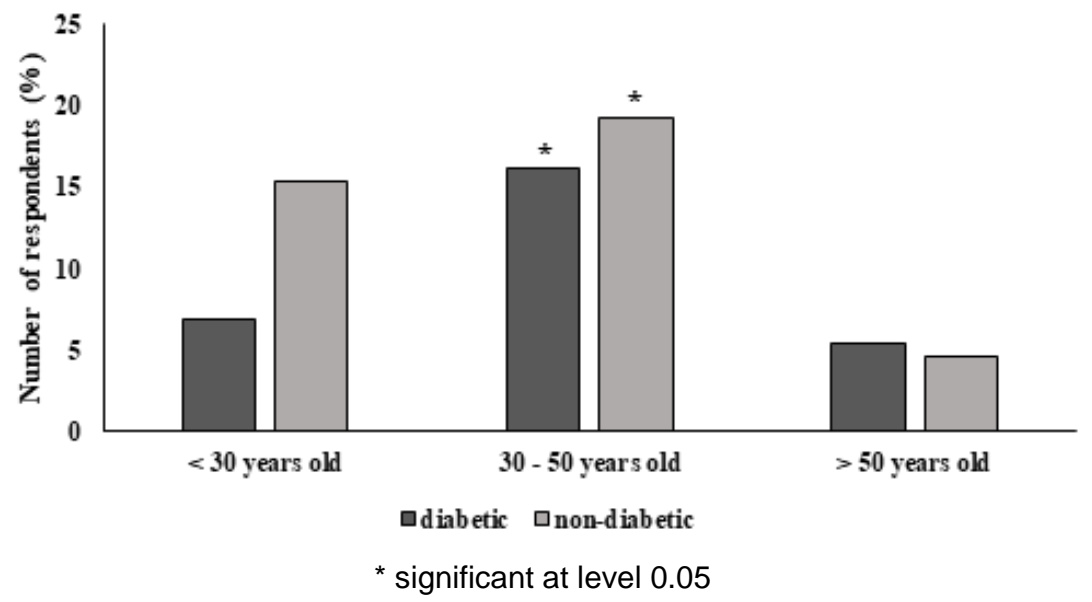

Graph 3. The frequency of traditional medicine use according to the age of respondents. Grafik 3. Frekventnost korišćenja tradicionalne medicine u odnosu na starost ispitanika

The most prevalent medicinal plants or / and supplements that were used by participants were peppermint $(21 \%)$, traditional herbal mixtures intended for maintaining normal glycemic values as well as for treating secondary diabetic complications (15\%), chamomile (13\%) and pharmaceutical supplements based on traditional medicine remedies $(10 \%)$. Other medicinal 
plants used by participants were ginger, shaggy mane, elder, cranberry, rose hip, eucalyptus, basil, common nettle, thyme, bearberry, marshmallow, lemon balm, lady's mantles, St John's wort, the pot marigold, hibiscus, burdock, yarrow, parsley, green tea, cinnamon, common sage, turmeric and oregano.

Most people purchase medicinal herbs and/or supplements in pharmacies (58\%) and from accredited medicinal herb sellers $(30 \%)$, while the smallest percentage of respondents buys on the local market (12\%).

\section{Discussion}

This study determined the prevalence of using ethnopharmacological therapies in Serbia. The research included two populations - people with diagnosed diabetes and people without diagnosed diabetes. 130 people were surveyed, and it was observed that $67,7 \%$ of them use traditional medicine in the form of medicinal plants and/or pharmaceutical supplements based on ethnopharmacological therapies.

These results, based on the survey conducted all over Serbia, differ from the previous studies, in which almost $90 \%$ of the population regularly used medicinal herbs in the territory of Niš (Damjanović et al, 2015), or in study where $100 \%$ of rural population in Serbia used traditional medicine in the treatment of chronic and acute diseases (Pieroni et al., 2011). Based on this, it could be concluded that depending on the territorial availability of health care centers, better economic status and higher education of the population, the prevalence of traditional medicine use is declining.

Bearing in mind that all the people with diabetes adhere to modern pharmacotherapy, while more than a quarter of non - diabetic persons relies exclusively on traditional medicine, we can gain a general insight into the state of the healthcare system in Serbia, that is, in case of severe chronic diseases such as diabetes, it is relatively simple to achieve a basic health care, but in the absence of chronic diseases with a serious clinical picture, even $26 \%$ of people do not seek advice from a doctor but rather turn to the traditional medicine.

The results of this study also show that women are more inclined to use traditional medicine, which corresponds to almost all previous studies conducted around the world.

The selection of supplements / medicinal herbs among respondents shows that they respect tradition over the popular global trend.

Most people buy medicinal herbs and/or supplements in pharmacies (58\%) and accredited medicinal herbal shops $(30 \%)$, while the smallest percentage of respondents buys on the local market (12\%), suggesting that the quality, as well as accessibility, are important to the respondents.

To conclude, the prevalence of CAM use in Serbia is high, and although all people with diabetes adhere to health care professionals' advice, more than a quarter of non - diabetic population relies exclusively on ethnopharmacological approaches, which points to certain shortcomings in the organization of the healthcare system.

\section{References}

Adusumilli, PS,. Ben-Porat, L., Pereira, M., Roesler, D. \& Leitman, M. (2004). The prevalence and predictors of herbal medicine use in surgical patients. J Am Coll Surg. 198, 583-590.

AlQathama, A. (2016) Natural Products \& Complementary Medicines: where are we up to? British Journal of Pharmacy. 1 (1). 
Argaex-Lopez, NWNH., Kumate-Rodriguez, J., Cruz, M., Talavera, J. \& Rivera-Arce, E. (2003) The Use of Complementary and Alternative Medicine Therapies in Type 2 Diabetic Patients in Mexico. Diabetes Care. 26(8), 2470.

Bell, RA., Suerken, CK., Grzywacz, JG., Quandt, SA. \& Arcury, TA. (2006) Complementary and alternative medicine use among adults with diabetes in the United States. Alternative Therapies in Health and Medicine.12(5), 16-22.

Bradshaw, ML. (2016). Knowledge, Attitudes, and Personal Use of Complementary and Alternative Medicine among Occupational Therapy Educators in the United States. Occupational Therapy In Health Care 30(1), 80-94.

Chang, HA., Wallis, M. \& Tiralongo E. (2011). Use of Complementary and Alternative Medicine among People with Type 2 Diabetes in Taiwan: A Cross-Sectional Survey. Evidence-Based Complementary and Alternative Medicine. Article ID 983792, 8 pages.

Damnjanović, I., Kitić, D., Stefanović, N., Zlatković-Guberinić, S., Catić-Đordjevic, A. \& Veličković-Radovanović, R. (2015). Herbal self-medication use in patients with diabetes mellitus type 2. Turkish Journal of Medical Sciences. 45(4), 964-971.

Esmonde, L. \& Long, AF. (2008). Complementary therapy use by persons with multiple sclerosis: benefits and research priorities. Complement Ther Clin Pract. 14, 176-184.

Farnsworth, NR., Akerele, OO., Bingel, AS., Soejarto, DD. \&Eno, Z. (1985). Medicinal plants in therapy. Bulletin World Health Organisation. 63, 965-981.

Fisher, P. \& Ward, A. (1994). Complementary medicine in Europe. BMJ. 309, 107-111.

Grand View Research, Inc. (2017). Alternative \& Complementary Medicine Market Worth \$196.87 Billion By 2025. https://www.grandviewresearch.com/press-release/global-alternative-complementarymedicine-therapies-market.

Hartel, U. \& Volger, E. (2004). Use and acceptance of classical natural and alternative medicine in Germany - findings of a representative population-based survey. Forsch Komplementarmed Klass Naturheilkd. 11, 327-334.

Hori, S., Mihaylov, I., Vasconcelos, J. \& McCoubrie, M. (2008) Patterns of complementary and alternative medicine use amongst outpatients in Tokyo, Japan. BMC Complementary and Alternative Medicine. 8 (14).

Institut za javno zdravlje Srbije "Dr Milan Jovanović Batut". (2017). Svetski dan dijabetesa. http://www.batut.org.rs/download/aktuelno/Saopstenje\%20za\%20javnost\%20povodom\%20Svets kog\%20dana\%20dijabetesa.pdf.

International Diabetes Federation. IDF. (2015). Diabetes Atlas, 7th edn. Brussels, Belgium: International Diabetes Federation, 2015. http://www.diabetesatlas.org.

Jatau, AI., Aung, MMT. Kamauzaman, THT., Chedi, BAZ., Sha'aban, A. \& Rahman, AFA. (2016). Use and toxicity of complementary and alternative medicines among patients visiting emergency department: Systematic review. Journal of Intercultural Ethnopharmacology 5(2), 191-197.

Jenkins, AJ., O’Neal Christopher, DN., Nolan, CJ. \& Januszewski, SJ. (2016) The Pathobiology of Diabetes Mellitus. Pancreatic Islet Biology. Stem Cell Biology and Regenerative Medicine. Humana Press. 1-48.

Kumar, D., Bajaj, S. \& Mehrotra, R. (2006). Knowledege, Attitude and Practice of Complementary and Alternative Medicines for Diabetes. Public Health.120(8), 705-711.

Manya, K., Champion, B. \& Dunning, T. (2012). The use of complementary and alternative medicine among people living with diabetes in Sydney. BMC Complementary and Alternative Medicine. $12(2)$.

National Institutes of Health, National Center for Complementary and Integrative Health (NCCIH). (2016). Americans Spent \$30.2 Billion Out-Of-Pocket On Complementary Health Approaches. https://nccih.nih.gov/news/press/cost-spending-06222016.

Nguyen, H., Sorkin, DH., Billimek, J., Kaplan, SH., Greenfield, S. \& Ngo-Metzger, Q. (2014). Complementary and Alternative Medicine (CAM) Use among Non-Hispanic White, Mexican American, and Vietnamese American Patients with Type 2 Diabetes, Health Care Poor Underserved. 25(4), 1941-19. 
Pieroni, A., Giusti, ME. \& Quave CL. (2011). Cross-Cultural Ethnobiology in the Western Balkans: Medical Ethnobotany and Ethnozoology Among Albanians and Serbs in the Pešter Plateau, Sandžak, South-Western Serbia, Hum Ecol. 39, 333-349.

Sheikhrabori, A, Mahlagha Dehghan, M., Ghaedi, F. \& Khademi, GR. (2017) Complementary and Alternative Medicine Usage and Its Determinant Factors Among Diabetic Patients: An Iranian Case, Journal of Evidence-Based Complementary \& Alternative Medicine. 22(3), 449-454.

Shikov, A., Pozharitskaya, O., Makarov, V., Wagner, H., Verpoorte, R. \& Heinrich, M. (2014). Medicinal Plants of the Russian Pharmacopoeia; their history and applications. Journal of Ethnopharmacology. 154, 481-536.

Snyder, M. \&Lindquist, R. (2009). Complementary and Alternative Therapies in Nursing. 6th ed. Berlin, Germany: Springer.

WHO. (2012). The Regional Strategy for Traditional Medicine in the Western Pacific (2011-2020). World Health Organization, Western Pacific Region.

\title{
ETNOFARMAKOLOŠKE TERAPIJE U LEČENJU DIJABETESA U SRBIJI
}

\author{
Višnja Madić, Andrea Žabar Popović, Marija Vukelić-Nikolić, \\ Ljubiša Đorđević, Perica Vasiljević
}

Sažetak. Korišćenje etnofarmakoloških terapija deo je ljudske tradicije. Vekovima se koriste kako u lečenju dijabetesa, tako i u terapiji drugih bolesti. Svrha ovog rada bila je ispitivanje učestalosti primene tradicionalne medicine u Srbiji. Ispitivanje je vršeno anketiranjem preko interneta, februara 2018. Ispitano je 130 ljudi, od kojih je 55,38 \% ispitanika bilo sa dijagnostifikovanim dijabetesom. Najčešće korišćeni herbalni supstituenti bili su $M$. piperita L. (21\%), tradicionalne biljne mešavine namenjene regulaciji primarnih i sekundarnih posledica dijabetesa (15\%), M. chamomilla L. (13\%) i farmaceutski suplementi zasnovani na tradicionalnim recepturama $(10 \%)$. Savremene farmakoterapije pridržava se $100 \%$ ljudi sa dijabetom, dok $25,86 \%$ ispitanika bez dijabeta ne koristi farmakoterapiju, već isključivo tradicionalnu medicinu. Nema bitne razlike među dijabetičnom populacijom koja koristi $(51,34 \%)$ i koja ne koristi etnofarmakološke tretmane $(48,61 \%)$, dok je u nedijabetičnoj populaciji razlika značajna $(p<0,05)$, pa tako $87,93 \%$ njih redovno primenjuje upotrebu lekovitih biljaka. Mnogo je više žena nego muškaraca sklonih etnofarmakološkim pristupima lečenja $(p<0,05)$. Starost ispitanika i njihovo obrazovanje takođe imaju uticaja na odabir terapije, pa su tako etnofarmakološki pristupi najzastupljeniji kod fakultetski obrazovanih ljudi starosti od 30 do 50 godina. Pokazalo se da ljudi obraćaju pažnju i na ispravnost suplemenata koje koriste, tj. 57,96 \% ljudi kupuje u apoteci, $29,55 \%$ kod sertifikovanih prodavaca, a samo $12,49 \%$ na pijaci.

Ključne reči: dijabetes, etnofarmakologija, farmakoterapija 